\title{
Relative condition factor: Le Cren's legacy for fisheries science
}

Fator de condição relativo: o legado de Le Cren para a ciência pesqueira

\author{
Éder André Gubiani1 ${ }^{1,2 *}$ (D), Renata Ruaro ${ }^{3}$ (D), Vinícius Ricardo Ribeiro ${ }^{1}$ (D) and \\ Úrsula Morgana Gomes de Santa Fé ${ }^{1}$ (D)
}

\begin{abstract}
${ }^{1}$ Programa de pós-graduação em Recursos Pesqueiros e Engenharia de Pesca, Grupo de Pesquisa em Recursos Pesqueiros e Limnologia, Universidade Estadual do Oeste do Paraná - UNIOESTE, rua da Faculdade, 645, Jardim Santa Maria, Toledo, PR, Brasil

${ }^{2}$ Programa de pós-graduação em Conservação e Manejo de Recursos Naturais, Universidade Estadual do Oeste do Paraná, Rua Universitária, 2069, Bairro Universitário, Cascavel, PR, Brasil

${ }^{3}$ Programa de pós-graduação em Ecologia de Ambientes Aquáticos Continentais, Universidade Estadual de Maringá, Avenida Colombo, 5790, Zona 7, Maringá, PR, Brasil

*e-mail: eder.gubiani@unioeste.br
\end{abstract}

Abstract: Aim: In this paper we present a scientometric analysis aimed at to assess and quantify the contribution of Le Cren's condition factor and the main ideas advanced by 'Le Cren, 1951' to studies on the health of individuals or populations in aquatic environments. Specifically, we addressed the following questions: (i) what are the temporal and spatial citation trends of 'Le Cren, 1951'?; (ii) Which journals cited 'Le Cren, 1951' most frequently?; (iii) In which types of aquatic environments and organisms have Le Cren's condition factor been most commonly applied?; (iv) Which of the main applications addressed in 'Le Cren, 1951' have been most frequently used by fisheries scientists?; (v) Which of the methods (i.e., Quételet's index or body mass index, Fulton's condition factor, Le Cren's condition factor, relative weight, residual index and scaled mass index) used to estimate condition factor identified in the papers that cited 'Le Cren, 1951' have been most frequently used? In addition, the main criticisms of the use of the relative condition factor are discussed. Methods: We carried out a scientometric analysis on the papers published from 1951 to December 2015 that cited Le Cren's article. The papers were obtained from the Thomson Reuters database (ISI Web of Knowledge, apps.isiknowledge.com) in May 2016. Results: In total, 1128 papers were assessed. The number of citations increased significantly over time. Most citations occurred in two journals (Journal of Fish Biology and Journal of Applied Ichthyology). Most of papers were carried out in marine environments. In addition, we show that Le Cren's paper has been cited mainly in articles that estimate the condition factor or the weight-length relationship of populations. Finally, we emphasize that the relative condition factor proposed by Le Cren in 1951 is still the main method used to estimate the body condition of an individual or population. Conclusions: Le Cren's significant contribution to animal well-being is undeniable, and we emphasize that among the methods identified in the papers that cited 'Le Cren, 1951' that estimated body condition, the relative condition factor proposed by Le Cren in 1951 is still the most commonly used method.

Keywords: Eric D. Le Cren; body condition; condition indices; length-weight relationship; aquatic ecosystems

Resumo: Objetivo: Assim, o objetivo deste trabalho foi realizar uma análise cienciométrica para avaliar e quantificar a contribuição do fator de condição relativo e das principais ideias propostas por 'Le Cren, 1951' em estudos sobre a saúde de um indivíduo ou população em ambientes aquáticos. Especificamente, respondemos as seguintes questóes (i) quais foram as tendências espaciais e temporais nas citaçóes de 'Le Cren, 1951'? (ii) quais revistas citaram 'Le Cren, 1951' mais frequentemente? 
(iii) em quais tipos de ambientes aquáticos e organismos o fator de condição relativo tem sido mais frequentemente aplicado? (iv) quais as principais aplicaçóes abordadas em 'Le Cren, 1951' foram mais frequentemente utilizadas por cientistas pesqueiros? E (v) quais métodos (i.e. índice de Quételet ou índice de massa corpórea, fator de condição de Fulton, fator de condição de Le Cren, peso relativo, índice residual ou índice de massa escalonado) usados para estimar o fator de condiçấo, identificados nos trabalhos que citaram 'Le Cren, 1951', têm sido mais frequentemente usados? Além disso, as principais críticas ao uso do fator de condição relativo são discutidas Métodos: Em maio de 2016, nós realizamos uma análise cienciométrica dos trabalhos publicados de 1951 a dezembro de 2015 que citaram o artigo de Le Cren utilizando a base de dados da Thomson Reuters (ISI Web of Knowledge, apps.isiknowledge.com). Resultados: Ao todo 1128 artigos foram contabilizados. O número de citaçôes aumentou significativamente ao longo do tempo. A maioria das citaçóes ocorreu em dois periódicos (Journal of Fish Biology and Journal of Applied Ichthyology). A maior parte dos artigos foi realizada em ambientes aquáticos. $\mathrm{O}$ artigo de Le Cren tem sido citado principalmente em artigos que estimaram o fator de condição ou a relação peso-comprimento de uma população. Além disso, nós enfatizamos que o fator de condição relativo proposto por Le Cren em 1951 ainda é o principal método utilizado para estimar a condição corporal de um indivíduo ou população. Conclusóes: Assim, a contribuição significativa de Le Cren para o estudo da saúde animal é inegável e nós enfatizamos que entre os métodos, identificados nos artigos que citaram 'Le Cren, 1951', para estimar a condição corporal, o fator de condição relativo proposto por Le Cren ainda é o mais utilizado.

Palavras-chave: Eric D. Le Cren; condição corporal; índices de condição; relação peso-comprimento; ecossistemas aquáticos

\section{Introduction}

Body condition is a key indicator of health at the individual or population level (e.g., Froese, 2006; Jakob et al., 1996; Labocha et al., 2014; Le Cren, 1951; Peig \& Green, 2009) since it is closely related to important fitness variables, such as growth (Lloret et al., 2002), reproduction (Bachman \& Widemo, 1999; Dobson \& Michener, 1995), behavior (Bachman \& Widemo, 1999), and survival (Jakob et al., 1996; Peig \& Green, 2009; 2010; Shine et al., 2001). The term "body condition" has been used in different manners, and it can mean different things. Commonly, the term is used to designate the energy reserves of an individual (Labocha et al., 2014; Peig \& Green, 2009). For example, animals with a better body condition are predicted to have more energy reserves (i.e., fat and protein), enabling them to endure longer periods of food shortage and present higher survival and reproductive success compared to animals with a poor body condition (Peig \& Green, 2009, 2010; Schulte-Hostedde et al., 2001, 2005; Shine et al., 2001). However, in some studies, body condition has been considered a measure of the biological and physical events that happen during some anterior period in the life cycle of an individual (Lloret $\&$ Ratz, 2000) or as an indicator of habitat quality and food availability (Johnson, 2007; Lloret et al., 2002).

Several indices have been proposed to measure body condition and indicate the nutritional and physiological status of individuals (Jacobs et al.,
2012; Labocha et al., 2014; Peig \& Green, 2010), and these indices can be classified as direct and destructive when the animals are slaughtered (i.e., gonadosomatic index: Chang \& Navas, 1984; Nikolsky, 1963; hepatosomatic or liversomatic index: Heidinger \& Crawford, 1977; and visceral somatic index: Delahunty \& de Vlaming, 1980) or as indirect and nondestructive when the animals are not slaughtered (i.e., Fulton's condition factor: Fulton, 1904; Hile, 1936; relative condition factor: Le Cren, 1951; and relative weight: Wege \& Anderson, 1978). Generally, indirect indices aim to determine the mass of an individual relative to its body size. Among them, the simplest are the so-called "ratio indices" (i.e., the body mass ratio divided by the body length), and one of the best known is Fulton's condition factor (see Froese, 2006), where the body length is raised to the power of three. Fulton's condition factor assumes that mass and length increase isometrically (Cone, 1989).

Fulton's condition factor was originally developed and applied in fisheries science (Fulton, 1904). However, many studies with fish (e.g., Bolger \& Connolly, 1989; Froese, 2006; Le Cren, 1951; Ricker, 1975) have shown that an increase in the weight and length of an individual is not isometric (weight-length relationship parameter, $\mathrm{b}<3$ or $\mathrm{b}>3$ ). In 1951, Le Cren (hereafter 'Le Cren, 1951') was the first to realize this in a seminal paper that evaluated the weight-length relationship, the seasonal cycle in gonad weight and the condition factor of Perca fluviatilis Linnaeus, 1758 , a common and widely distributed perciform 
fish found throughout Europe and Asia. Le Cren proposed the relative condition factor $\left(\mathrm{K}_{\mathrm{n}}\right)$, in which the observed mass of an individual is divided by its predicted mass, which is obtained from the linear regression of the weight-length relationship of the respective population sample (Le Cren, 1951). This article became a classic citation, especially in fisheries science (Lowe-McConnell, 2011).

Although widely used, there are several criticisms of Le Cren's condition factor regarding its application (Bolger \& Connolly, 1989; Peig \& Green, 2010). The main criticism is that it does not allow comparisons between populations, unless they have the same weight-length relationship. However, the relative condition factor allows comparisons of the conditions of different individuals from the same sample independent of length (Froese, 2006). Despite the pros and cons of its use and application, the paper by 'Le Cren, 1951' was a pioneer due to its contribution to the understanding and discussion of animal body condition.

In this paper we present a scientometric analysis aimed to assess and quantify the contribution of Le Cren's condition factor and the main ideas advanced by 'Le Cren, 1951' to studies on the health of an individual or population in aquatic environments. Specifically, we addressed the following questions: (i) what are the temporal and spatial citation trends of 'Le Cren, 1951'?; (ii) Which journals cited 'Le Cren, 1951' most frequently?; (iii) In which types of aquatic environments and organisms have Le Cren's condition factor been most commonly applied?; (iv) Which of the main applications addressed in 'Le Cren, 1951' have been most frequently used by fisheries scientists?; (v) Which of the methods (i.e., Quételet's index or body mass index, Fulton's condition factor, Le Cren's condition factor, relative weight, residual index and scaled mass index) used to estimate condition factor identified in the papers that cited 'Le Cren, 1951' have been most frequently used? In addition, the main criticisms of the use of the relative condition factor are discussed.

\section{Materials and Methods}

In May 2016, we carried out a scientometric analysis using the Thomson Reuters database (ISI Web of Knowledge, apps.isiknowledge.com) and compiled a list of all the papers that cited 'Le Cren, 1951'. We identified the country of the first author of each paper, which was subsequently grouped by continent, in the journals that cited 'Le Cren, 1951' and the temporal trends in the citations. In addition, we assessed the citation rank of 'Le Cren, 1951' among all the papers published in the Journal of Animal Ecology, the journal in which Le Cren's paper was originally published.

To complete objectives iii to $\mathrm{v}$, we selected a subsample $(\approx 40 \%$, which returned an adequate sample without losing reliability in the results) of the articles that cited 'Le Cren, 1951' by using the "subset/random" option in the software Statistica 7.0. We did this because more detailed analyses were difficult since abstracts were only available after 1990 and the number of papers was substantial. Thus, we obtained copies of all the selected papers in the subsample that cited 'Le Cren, 1951' and analyzed them in detail. These papers were categorized as theoretical or empirical. The empirical studies were categorized according to the main type of ecosystem, i.e., terrestrial, marine or freshwater studies. To further analyze this issue, only empirical aquatic studies were used. From this, the studies were grouped to answer the following questions: (a) in which type of aquatic environment (ocean, salt marsh, intertidal zone or estuary (for marine studies), river/stream, lagoon, reservoir, pond, wetland or laboratorial experiment (for freshwater)) was the study carried out; and (b) which organisms were studied: molluscs, crustaceans, insects, fishes, reptiles, birds, mammals or multispecies.

In addition, in an attempt to identify the main use/application of the ideas presented in 'Le Cren, 1951', we quantified the papers that estimated the condition factor and the weight-length relationship. On the other hand, to differentiate from the above information cited, we also counted the number of papers that only cited 'Le Cren, 1951'. Finally, different methods have been used to estimate the condition factor (Table 1). Although our research is skewed to those papers that cited 'Le Cren, 1951 ', we expect that all of the articles estimating the condition factor would have cited 'Le Cren, 1951'. Thus, we quantified which method was used to estimate the condition factor in the papers selected in our sample. In addition, we highlighted some limitations regarding the use of the relative condition factor proposed by 'Le Cren, 1951'.

The presented data do not necessarily represent the number of papers but rather the information included in the studies because not all the articles presented all the information of interest; additionally, the numbers included in the analyses were not always the same because the papers were counted multiple times when necessary (e.g., some studies were conducted in more than one country or aquatic environment). Hence, we counted and presented the total amount of data per analysis (Table 2). 
Table 1. Methods used to estimate the condition factor and their respective references and equations that were identified in the papers that cited 'Le Cren, 1951' based on a search from 1951 to December 2015.

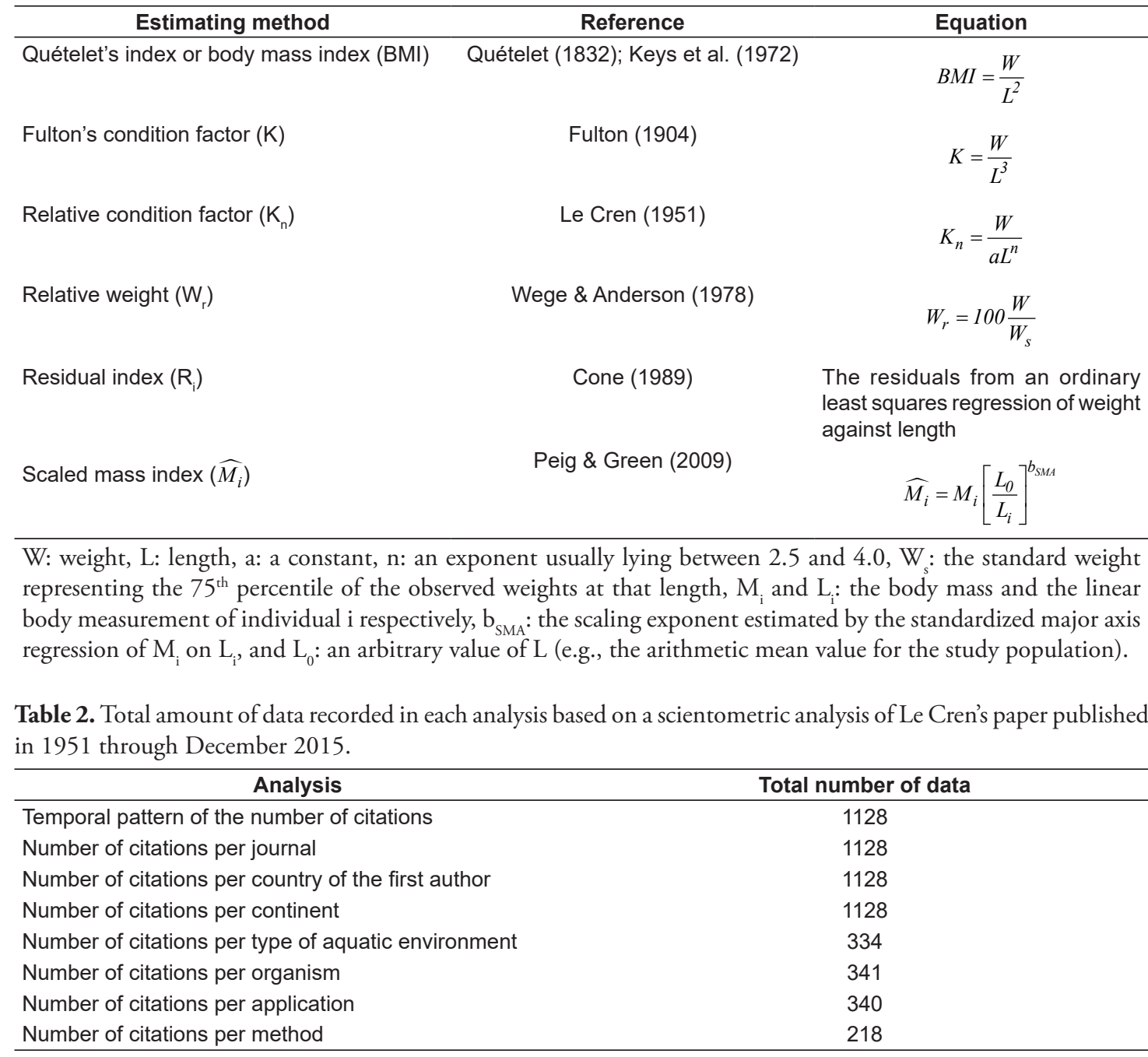

\section{Results}

A total of 1128 papers have cited 'Le Cren, 1951' from 1957 to December 2015. The number of citations increased significantly over time (nonlinear fit, $r=0.79, p<0.01$ ), reaching the maximum of 95 citations in 2015 (Figure 1). 'Le Cren, 1951' was cited by articles published in 280 journals. Most of the citations occurred in journals focusing on fisheries and marine and freshwater biology, with approximately $14 \%$ of the citations concentrated in two journals: the Journal of Fish Biology and the Journal of Applied Ichthyology (Figure 2). In addition, citations were also found in journals focusing on ecology, veterinary sciences, animal husbandry and environmental sciences. Among all 5100 papers published by the Journal of Animal Ecology through December 2015, Le Cren's 1951 article was the $3^{\text {rd }}$ most cited (1078 citations, Figure 3 ).

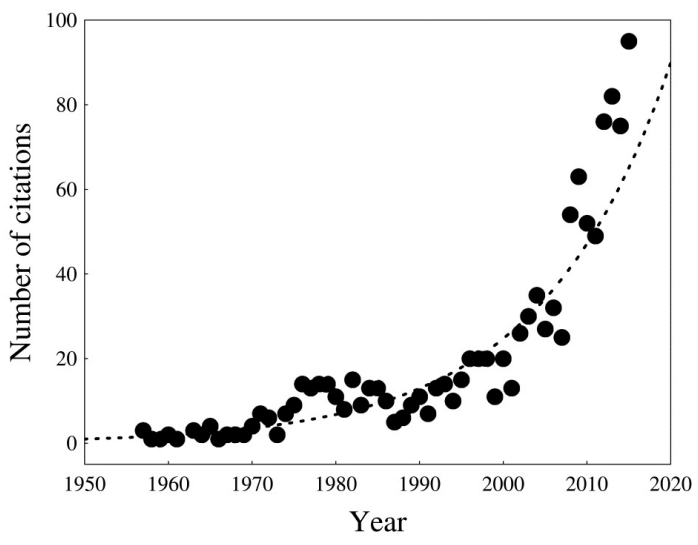

Figure 1. Temporal trend in the number of papers citing 'Le Cren, 1951' based on a search from 1951 to December 2015.

The subsampling process resulted in the selection of 450 articles. From these papers, most of the citations came from Europe (33\%), and the 


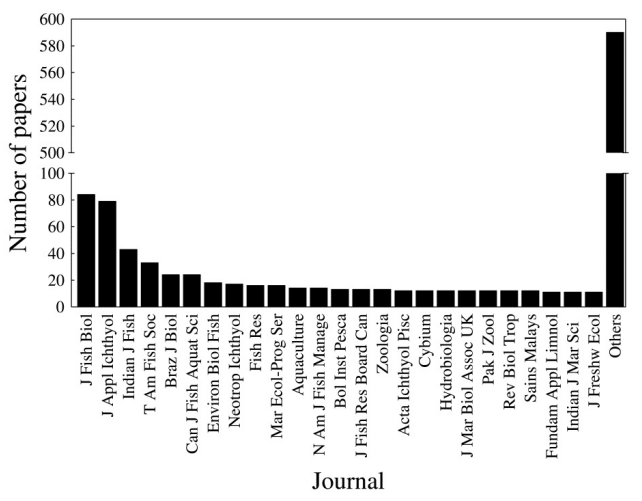

Figure 2. Number of papers published in different journals that cited 'Le Cren, 1951' based on a search from 1951 to December 2015.

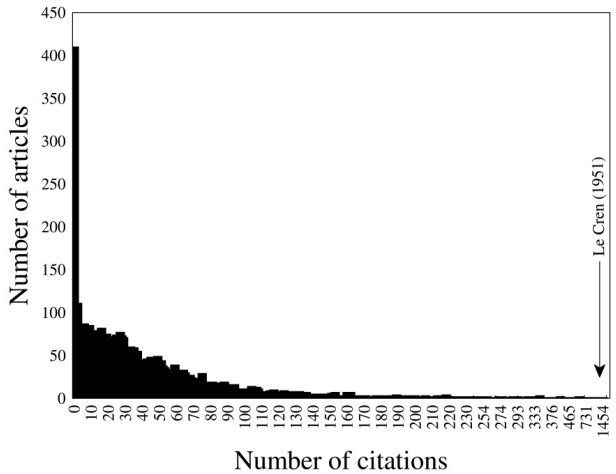

Figure 3. Histogram of the number of citations of the articles published between 1945 and 2015 in the Journal of Animal Ecology based on a search carried out in May 2016. Le Cren's paper is highlighted.
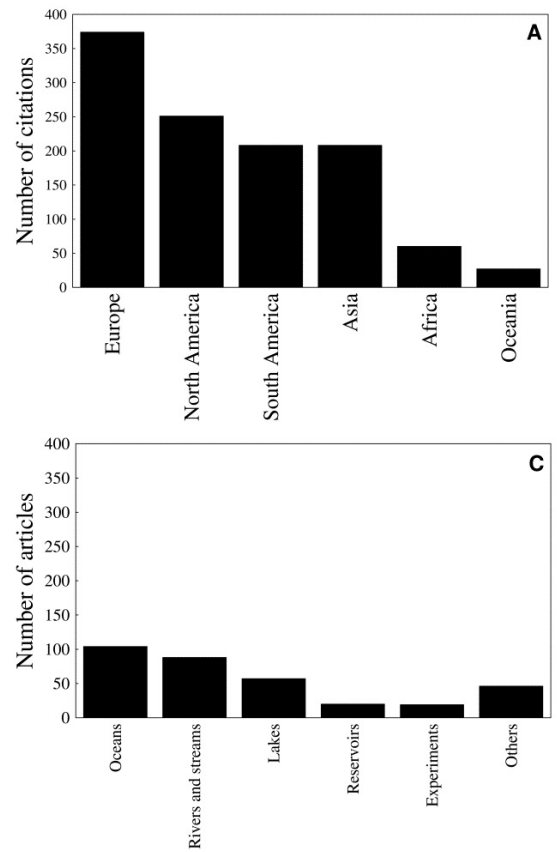

lowest number of citations came from Oceania (2\%; Figure 4A). Seventy-six countries were recorded in the citations. Five countries (Brazil, the United States of America, India, the United Kingdom and Canada; Figure 4B) accounted for $54 \%$ of the citations. In most of the citations, the article's first author was from Brazil (16\%; Figure 4B). Most studies that cited Le Cren's paper were carried out on oceans (31\%; Figure 4C). In contrast, only $6 \%$ of the citations came from research on reservoirs and laboratorial experimental studies (Figure 4C).

Almost all of the papers that cited 'Le Cren, 1951 'studied fish (91\% of the papers; Figure 4D). Some of the studies assessed more than one group of organisms. Two main applications of Le Cren's paper were identified (Figure 5): estimations of the relative condition factor ( $46 \%$ of the citations) and the fit of the weight-length relationship of a population (37\% of the citations). In addition, $13 \%$ of the papers included both main applications (Figure 5). Thus, $96 \%$ of the selected articles used at least one of these two main applications.

The main application of Le Cren's paper was estimating the relative condition factor, and consequently, his method was the most widely used for this estimate ( $44 \%$ of the papers; Figure 6) based on papers that cited 'Le Cren, 1951'. Five other methods for estimating the condition factor was also cited (Figure 6, Table 1).
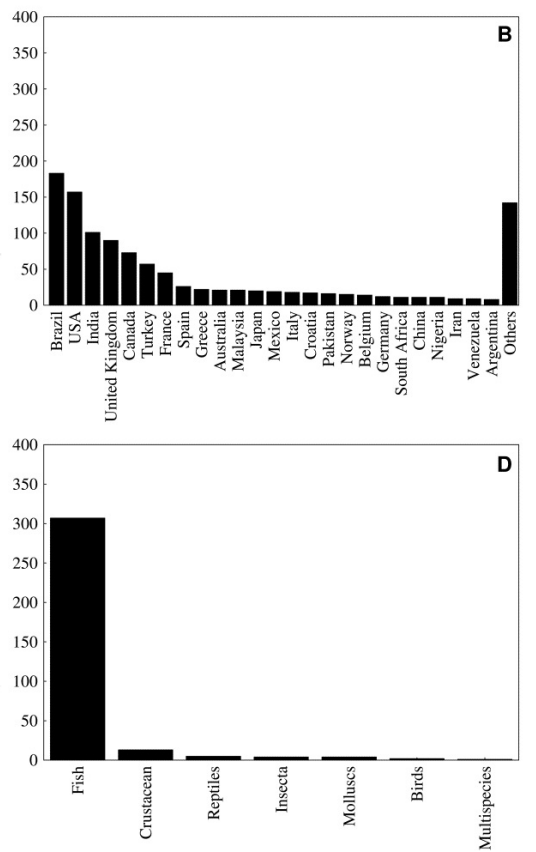

Figure 4. Number of citations of Le Cren's (1951) paper (A) per continent and (B) per country of the first author and the number of articles that cited 'Le Cren, 1951' (C) per type of aquatic environment and (D) per organism based on a search from 1951 to December 2015. 


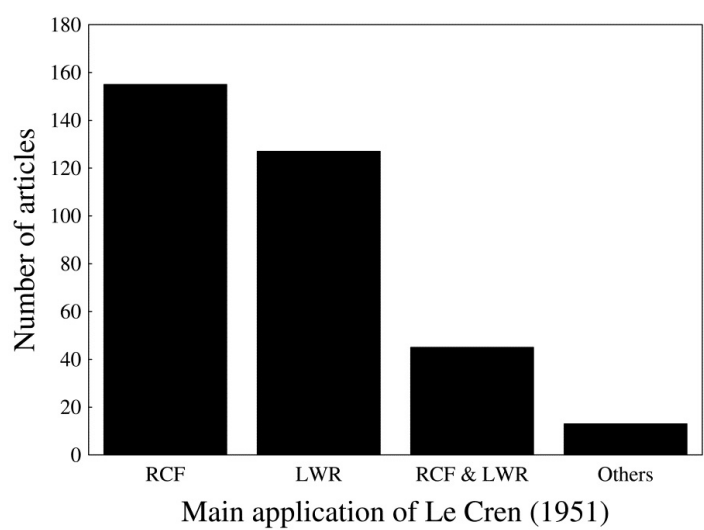

Figure 5. Main application of the ideas advanced by 'Le Cren, 1951' identified in a subsample of the articles that cited 'Le Cren, 1951' based on a search from 1951 to December 2015. RCF = relative condition factor; LWR = length-weight relationship.

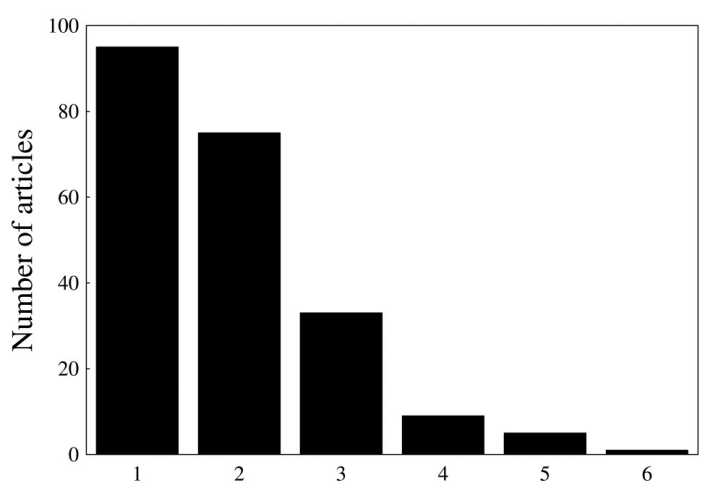

Estimating method for condition factor

Figure 6. Methods used to estimate the body condition factor identified in the papers that cited 'Le Cren, 1951' based on a search from 1951 to December 2015. 1: Le Cren's condition factor; 2: Fulton's condition factor; 3: relative weight; 4: Quételet's index or body mass index; 5: residual index; and 6: scaled mass index (for more details, see Table 1).

\section{Discussion}

The increase in the number of citations over time provides evidence of the important contribution and influence of Le Cren's paper on the study of animal body condition. The number of citations has increased considerably since 2000, similar to the trend observed in science in Brazil (De Meis et al., 2007; Regalado, 2010), possibly because at large number of papers became available online (Schäfer et al., 2011; Souza et al., 2010) and important journals addressing issues on body condition emerged during this period (i.e., Neotropical Ichthyology and Journal of Applied Ichthyology). 'Le Cren, 1951' has been most frequently cited in scientific journals targeting fisheries and the biology of freshwater and marine fishes, and it is the third most frequently cited paper in the Journal of Animal Ecology. Additionally, the Journal of Fish Biology and the Journal of Applied Ichthyology had many published papers that cited 'Le Cren, 1951'. These are traditional journals in fish biology because they exclusively publish articles related to fisheries and the biology of freshwater and marine fishes and cover all aquatic ecosystems (marine, estuary and freshwater). The first citation recorded in our research was made in 1957 by Timothy B. Bagenal, in an article titled "The breeding and fecundity of the long rough dab Hippoglossoides platessoides (Fabr.) and the associated cycle in condition". The European continent had the highest proportion of articles that cited 'Le Cren, 1951'. In contrast, there were few articles from Oceania and Africa.

Although a majority of the articles included research carried out in Europe, Brazil was the country with the higher number of first authors of papers that cited 'Le Cren, 1951'. Brazilian territory support great diversity of fish species (Reis et al., 2003; 2016; Lewinsohn \& Prado, 2005; Toussaint et al., 2016). In addition, in recent years, aquaculture has intensified in Brazil, which may have contributed to the number of studies focusing on the body condition of fishes (Barone et al., 2017; Pelicice et al., 2017).

Fish were the most studied organisms in the papers that cited 'Le Cren, 1951'. Consequently, oceans, rivers and streams were the most studied aquatic environments. In this way, 'Le Cren, 1951' has been cited in many papers related to fisheries biology and fisheries management (Froese, 2006; Froese et al., 2011).

As demonstrated by our results, the paper by 'Le Cren, 1951' was mainly cited in articles that assessed the condition factor and the weight-length relationship in fish species. According to Froese (2006), in a meta-analysis on the condition factor and the weight-length relationship in fish, the historical development of these two metrics is intertwined because heavier fish of a given length are in better condition. Thus, Le Cren's paper was cited both in articles that estimated only the weight-length relationship corresponding to a given length and in those that determined the condition factor by comparing the 'condition', 'fatness' or 'well-being' of fish. This pattern was evident in our results, in which $96 \%$ of the articles primarily cited 'Le Cren, 1951' either in the estimation of the condition factor or the weight-length relationship. 
The interconnectedness of the condition factor and the weight-length relationship is also justified because the study of animal condition is usually based on the fit of the weight-length relationship. One of the most common methods for determining an individual's body condition is fitting the linear relationship between body mass and some measure of size. For example, in fish, the most commonly used method is fitting a linear regression model between body mass and the standard length, a measure of a fish's body length from the tip of its nose to end of its last vertebrae, both of which are log-transformed. From this fit, which is usually determined by ordinary least squares regression, the residuals from this relationship are used as an index of body condition, where positive residuals indicate individuals with a better body condition and negative residuals indicate individuals with a poor body condition (Jakob et al., 1996; SchulteHostedde et al., 2001, 2005).

The relative condition factor $\left(\mathrm{K}_{\mathrm{n}}\right.$; Le Cren, $1951)$ is the most applied index for estimating the body condition of fish. However, several criticisms of its application have been noted by many authors (Bolger \& Connolly, 1989; Froese, 2006; Labocha \& Hayes, 2012; Peig \& Green, 2009; Schulte-Hostedde et al., 2005). The main criticism highlights the fact that the index is usually correlated with any linear measurement of body size (Froese, 2006; Jakob et al., 1996; Peig \& Green, 2009), and it does not allow comparisons across populations (Bolger \& Connolly, 1989; Froese, 2006; Labocha et al., 2014). Given that an individual's body condition may be influenced by innumerable factors, such as sex, season, and the degree of gonadal development (Froese, 2006; Froese et al., 2011; Le Cren, 1951), the weight-length relationship may not be the same among different populations.

Recently, new methods for estimating the body condition of an individual have been described (Peig \& Green, 2009, 2010; Viblanc et al., 2012). However, the choice of which index is best is still a question that remains unanswered by scientists (Jakob et al., 1996; Labocha et al., 2014; Peig \& Green, 2010). Despite criticisms on the use of the relative condition factor developed by Le Cren (1951), its recent use is still quite evident, especially within fisheries sciences. Thus, according to Froese (2006), when evaluating within-species variation in weight-length relationships and estimating the relative condition of individuals within a sample, Le Cren's condition factor is recommended. Therefore, as highlighted above, this index can be very useful for fisheries management purposes.

In summary, we showed that the article published by Le Cren in 1951 is a classic paper that furthered the understanding of the body condition or well-being of an individual. According to our results, it is the third most cited article in the Journal of Animal Ecology. In addition, the article's legacy remains evident, especially in fisheries sciences, given the large number of recent citations in articles that applied the relative condition factor or fitted weight-length relationships for fish. Finally, given the limitation of our sample, we emphasize that among the methods identified in the papers that cited 'Le Cren, 1951' for estimating body condition, the relative condition factor proposed by Le Cren in 1951 is still the most commonly used method.

\section{Acknowledgements}

This study was financed in part by the Coordenação de Aperfeiçoamento de Pessoal de Nível Superior - Brasil (CAPES/Ministério da Educação) - Finance Code 001. U. M. G. de Santa Fé is also grateful to the CAPES for her scholarships. R. Ruaro is grateful to the Conselho Nacional de Desenvolvimento Científico e Tecnológico (CNPq/Ministério da Ciência, Tecnologia, Inovações e Comunicaçóes) for her scholarships. É. A. Gubiani is also grateful to the CNPq for the continuous research productivity grants (PQ Process Number: 308578/2017-1).

\section{References}

BACHMAN, G. and WIDEMO, F. Relationships between body composition, body size and alternative reproductive tactics in a lekking sandpiper, the Ruff (Philomachus pugnax). Functional Ecology, 1999, 13(3), 411-416. http://dx.doi.org/10.1046/j.13652435.1999.00323.x.

BARONE, R.S.C., LORENZ, E.K., SONODA, D.Y. and CYRINO, J.E.P. Fish and fishery products trade in Brazil, 2005 to 2015: A review of available data and trends. Scientia Agrícola, 2017, 74(5), 417-424. http://dx.doi.org/10.1590/1678-992x-2016-0300.

BOLGER, T. and CONNOLLY, P.L. The selection of suitable indices for the measurement and analysis of fish condition. Journal of Fish Biology, 1989, 34(2), 171182. http://dx.doi.org/10.1111/j.1095-8649.1989. tb03300.x.

CHANG, B.D. and NAVAS, W. Seasonal variation in growth, condition and gonads of Dormitator latifrons (Richardson) in the Chone River basin, Ecuador. Journal of Fish Biology, 1984, 24(6), 637-648. http:// dx.doi.org/10.1111/j.1095-8649.1984.tb04834.x. 
CONE, R.S. The need to reconsider the use of condition indices in fishery science. Transactions of the American Fisheries Society, 1989, 118(5), 510-514. http://dx.doi. org/10.1577/1548-8659(1989)118<0511:TNTRT $\mathrm{U}>2.3 . \mathrm{CO} ; 2$.

DE MEIS, L., ARRUDA, A.P. and GUIMARÁES, $\mathrm{J}$. The impact of science in Brazil. International Union of Biochemistry and Molecular Biology life, 2007, 59(4-5), 227-234. http://dx.doi. org/10.1080/15216540701258140

DELAHUNTY, G. and DE VLAMING, V.L. Seasonal relationships of ovary weight, liver weight and fat stores with body weight in the goldfish, Carassius auratus (L.). Journal of Fish Biology, 1980, 16(1), 5-13. http://dx.doi.org/10.1111/j.1095-8649.1980. tb03683.x.

DOBSON, F.S. and MICHENER, G.R. Maternal traits and reproduction in Richardson's ground squirrels. Ecology, 1995, 76(3), 851-862. http://dx.doi. org/10.2307/1939350.

FROESE, R. Cube law, condition factor and weightlength relationships: History, meta-analysis and recommendations. Journal of Applied Ichthyology, 2006, 22(4), 241-253. http://dx.doi.org/10.1111/ j.1439-0426.2006.00805.x.

FROESE, R., TSIKLIRAS, A.C. and STERGIOU, K.I. Editorial note on weight-length relations of fishes. Acta Ichthyologica et Piscatoria, 2011, 41(4), 261-263. http://dx.doi.org/10.3750/AIP2011.41.4.01.

FULTON, T.W. The rate of growth offishes. Twenty-second Annual Report, Part III. Edinburgh: Fisheries Board of Scotland, 1904, pp. 141-241.

HEIDINGER, R.C. and CRAWFORD, S.D. Effect of temperature and feeding rate on the liver-somatic index of the largemouth bass, Micropterus salmoides. Journal of the Fisheries Research Board of Canada, 1977, 34(5), 633-638. http://dx.doi.org/10.1139/ f77-099.

HILE, R. Age and growth of the cisco, Leucichthys artedi (LeSuer), in the lakes of the northeastern highlands, Wisconsin. Bulletin of the United States Bureau of Fisheries, 1936, 48, 211-317.

JACOBS, S.R., ELLIOTT, K., GUIGUENO, M.F., GASTON, A.J., REDMAN, P., SPEAKMAN, J.R. and WEBER, J.M. Determining seabird body condition using nonlethal measures. Physiological and Biochemical Zoology, 2012, 85(1), 85-95. http:// dx.doi.org/10.1086/663832. PMid:22237292.

JAKOB, E.M., MARSHALL, S.D. and UETZ, G.W. Estimating fitness: a comparison of body condition indices. Oikos, 1996, 77(1), 61-67. http://dx.doi. org/10.2307/3545585.

JOHNSON, M.D. Measuring habitat quality: A review. The Condor, 2007, 109(3), 489-504. http://dx.doi. org/10.1093/condor/109.3.489.
KEYS, A., FIDANZA, F., KARVONEN, M.J., KIMURA, N. and TAYLOR, H.L. Indices of relative weight and adiposity. Journal of Chronic Diseases, 1972, 25(6), 329-343. http://dx.doi.org/10.1016/00219681(72)90027-6. PMid:4650929.

LABOCHA, M.K. and HAYES, J.P. Morphometric indices of body condition in birds: a review. Journal of Ornithology, 2012, 153(1), 1-22. http://dx.doi. org/10.1007/s10336-011-0706-1.

LABOCHA, M.K., SCHUTZ, H. and HAYES, J.P. Which body condition index is best? Oikos, 2014 , 123(1), 111-119. http://dx.doi.org/10.1111/j.16000706.2013.00755.x.

LE CREN, E.D. The length-weight relationship and seasonal cycle in gonad weight and condition in the perch (Perca fluviatilis). Journal of Animal Ecology, 1951, 20(2), 201-219. http://dx.doi. org/10.2307/1540.

LEWINSOHN, T.M. and PRADO, P.I. How many species are there in Brazil? Conservation Biology, 2005, 19(3), 619-624. http://dx.doi.org/10.1111/j.15231739.2005.00680.x.

LLORET, J. and RATZ, H.J. Condition of cod (Gadus morhua) off Greenland during 1982-1998. Fisheries Research, 2000, 48(1), 79-86. http://dx.doi. org/10.1016/S0165-7836(00)00111-9.

LLORET, J., DE SOLA, L.G., SOUPLET, A. and GALZIN, R. Effects of large-scale habitat variability on condition of demersal exploited fish in the northwestern Mediterranean. ICES Journal of Marine Science, 2002, 59(6), 1215-1227. http://dx.doi. org/10.1006/jmsc.2002.1294.

LOWE-MCCONNELL, R. Eric David Le Cren $1922-$ 2011 (Freshwater Biological Association). Journal of Fish Biology, 2011, 79(7), 1681-1684. http://dx.doi. org/10.1111/j.1095-8649.2011.03168.x.

NIKOLSKY, G.V. The ecology of fishes. New York: Academic Press, 1963, 352 p.

PEIG, J. and GREEN, A.J. New perspectives for estimating body condition from mass/length data: the scaled mass index as an alternative method. Oikos, 2009, 118(12), 1883-1891. http://dx.doi. org/10.1111/j.1600-0706.2009.17643.x.

PEIG, J. and GREEN, A.J. The paradigm of body condition: a critical reappraisal of current methods based on mass and length. Functional Ecology, 2010, 24(6), 1323-1332. http://dx.doi.org/10.1111/ j.1365-2435.2010.01751.x.

PELICICE, F.M., AZEVEDO-SANTOS, V.M., VITULE, J.R.S., ORSI, M.L., LIMA JUNIOR, D.P., MAGALHÃES, A.L.B. and POMPEU, P.S., PETRERE JUNIOR, M. and AGOSTINHO, A.A. Neotropical freshwater fishes imperilled by unsustainable policies. Fish and Fisheries, 2017, 18(6), 1119-1133. http://dx.doi.org/10.1111/faf.12228. 
QUÉTELET, A. Recherches sur le poids de l'homme aux different âges. vol. 7. Bruxelles: Nouveaux Memoire de l'Academie Royale des Sciences et Belles-Lettres de Bruxelles, 1832.

REGALADO, A. Brazilian Science: riding a gusher. Science, 2010, 330(6009), 1306-1312. http:// dx.doi.org/10.1126/science.330.6009.1306. PMid:21127226.

REIS, R.E., ALBERT, J.S., DI DARIO, F., MINCARONE, M.M., PETRY, P. and ROCHA, L.A. Fish biodiversity and conservation in South America. Journal of Fish Biology, 2016, 89(1), 12-47. http://dx.doi.org/10.1111/jfb.13016. PMid:27312713.

REIS, R.E., KULLANDER, O. and FERRARIS JUNIOR, C.J. Check list of the freshwater fishes of South and Central America. Porto Alegre: EDIPUCRS, 2003, 742 p.

RICKER, W.E. Computation and interpretation of the biological statistics of fish populations. Bulletin Fisheries Research Board of Canada, 1975, 191, 1-382.

SCHÄFER, R.B., COOKE, S.J., ARLINGHAUS, R., BONADA, N., BRISCHOUX, F., CASPER, A.F., CATFORD, J.A. and ROLLAND, V. Perspectives from early career researchers on the publication process in ecology - a response to Statzner and Resh (2010). Freshwater Biology, 2011, 56(11), 2405-2412. http://dx.doi.org/10.1111/j.13652427.2011.02673.x.

SCHULTE-HOSTEDDE, A.I., MILLAR, J.S. and HICKLING, G.J. Evaluating body condition in small mammals. Canadian Journal of Zoology, 2001, 79(6), 1021-1029. http://dx.doi.org/10.1139/ z01-073.

SCHULTE-HOSTEDDE, A.I., ZINNER, B., MILLAR, J.S. and HICKLING, G.J. Restitution of mass-size residuals: validating body condition indices. Ecology, 2005, 86(1), 155-163. http://dx.doi. org/10.1890/04-0232.
SHINE, R., LEMASTER, M.P., MOORE, I.T., OLSSON, M.M. and MASON, R.T. Bumpus in the snake den: effects of sex, size, and body condition on mortality of red-sided garter snakes. Evolution; International Journal of Organic Evolution, 2001, 55(3), 598-604. http://dx.doi.org/10.1554/00143820(2001)055[0598:BITSDE]2.0.CO;2. PMid:11327166.

SOUZA, E.P.S., CABRERA, E.M.S. and BRAILE, D.M. The article of the future. Revista Brasileira de Cirurgia Cardiovascular; Orgao Oficial da Sociedade Brasileira de Cirurgia Cardiovascular, 2010, 25(2), 141-148. http://dx.doi.org/10.1590/S010276382010000200003 . PMid:20802903.

TOUSSAINT, A., CHARPIN, N., BROSSE, S. and VILLÉGER, S. Global functional diversity of freshwater fish is concentrated in the Neotropics while functional vulnerability is widespread. Scientific Reports, 2016, 6(1), 22125. http://dx.doi. org/10.1038/srep22125. PMid:26980070.

VIBLANC, V.A., BIZE, P., CRISCUOLO, F., LE VAILLANT, M., SARAUX, C., PARDONNET, S., GINESTE, B., KAUFFMANN, M., PRUD'HOMME, O., HANDRICH, Y., MASSEMIN, S., GROSCOLAS, R. and ROBIN, J.P. Body girth as an alternative to body mass for establishing condition indexes in field studies: a validation in the king penguin. Physiological and Biochemical Zoology, 2012, 85(5), 533-542. http:// dx.doi.org/10.1086/667540. PMid:22902382.

WEGE, G.J. and ANDERSON, R.O. Relative weight (Wr): a new index of condition of largemouth bass. In: G.D. Novinger and J.D. Dillard, eds. New approaches to the management of small impoundments. Bethesda, Maryland: North Central Division, American Fisheries Society Special Publication, 1978, pp. 79-91.

Received: 07 December 2017 Accepted: 28 November 2019 